\title{
The Revolving Door: State Connections and Inequality of Influence in the US Banking Sector
}

\author{
Elise S. Brezis* and Joël Cariolle**
}

\begin{abstract}
This paper addresses the effects of the revolving door phenomenon on the inequality of influence among firms. It shows that firms are not equal in their capacities to benefit from state connections.

We first develop a theoretical model introducing the notion of 'bureaucratic capital' and showing how the revolving door generates inequality in bureaucratic capital and in profits leading to inequality of influence. Then, this prediction is tested on a new database tracking the revolving door process involving the 20 biggest US commercial banks. We show that regulators who have created a large stock of 'bureaucratic capital' are more likely to be hired by the top five banks after leaving public office.

We then develop indices of the inequality of influence between banks. We show that banks in the top revenue quintile concentrate around $80 \%$ of the stock of revolvers. Goldman Sachs appears as the prime beneficiary of this process, by concentrating almost $30 \%$ of the revolving door phenomenon.
\end{abstract}

Keywords: regulators, revolving door, rent-seeking, state connections, bureaucratic capital, inequality of influence, connected firms, corruption, unethical behavior.

JEL classification: D73; G01; G18; L51.

* Department of Economics, Bar-Ilan University, Israel, E-mail: elise.brezis@ biu.ac.il

** FERDI, Clermont-Ferrand, France. E-mail: joel.cariolle@ ferdi.fr

We are grateful to Janos Bartok, Gonzalo Caballero, François Facchini, Vincenzo Galasso, Bernard Gauthier, Martin Gassebner, Nicolas Gavoille, Jacob de Haan, Jesper Johnson, Florian Léon, Frederic Lesné, Christian Lessmann, Catherine Mann, Marc Sangnier, Norman Schofield, as well as participants at the U4-Proxy Challenge Competition, the European Public Choice Society meeting, the CESifo workshop on Political Economy, and the ICOPEAI conference, for their valuable comments. We thank Gina $\mathrm{Li}$ and Hoa Duong for excellent research assistance. 


\section{Introduction}

This paper explains why the revolving door generates inequality of influence between firms and distorts the economy. We show that big companies can afford to hire many revolvers and benefit from them, while small firms in the same sector cannot afford this strategy. This disparity and unequal competition in the numbers of revolvers are what this paper analyzes.

Although our paper focuses mainly on the differences between firms in their capacity to hire revolvers and in the resulting inequality in profits, the revolving door phenomenon -defined as so when heads of state agencies, after completing their bureaucratic terms, are entering the very sector they have regulated -- is mostly analyzed in a macro-context. Indeed, lately, the revolving door phenomenon which has intensified, has been widely documented as having negative effects on the economy. ${ }^{1}$ More specifically, the 'revolving door' has been blamed as being a major cause of the 2008 crisis, due to conflicts of interests, and connections between the highest levels of governments and private financial groups (OECD, 2009).

The literature on the negative effects of the revolving door has focuses on the well-known Regulatory capture channel, which occurs when a regulator is "captured" by one specific firm, and while strict with the others, she is lenient with this firm in order to be hired by it after leaving office. Laffont and Tirole (1996) stressed that in OECD countries where explicit bribes cannot be paid without being noticed; this phenomenon is an important vehicle for corrupt deals leading to lenient regulations, and in turn public resources misallocation. Indeed, this form of revolving door is unlawful in most countries, and is considered to be corruption. Yet it is difficult to believe that the revolving door, which is in so much use around the Western world, is related to unlawful behavior.

This paper takes a different approach: it analyzes the practice of the revolving door in a legal environment, and focuses on the differences of behavior between firms. The revolving door in our approach is related to rent-seeking, and represents an unethical yet legal behavior.

The regulators and the firms hiring them behave legally but unethically in the following way: Regulators accumulates during their public office a specific human capital called

\footnotetext{
${ }^{1}$ See www.openSecrets.org, and Lucca et al., (2014). Moreover, research conducted by Corporate Europe Observatory has shown that the phenomenon has become significant also in EU institutions. See http://corporateEurope.org/revolvingDoorWatch, and also Transparency International-UK, (2011).
} 
bureaucratic capital. 'Bureaucratic capital' is the capital the regulator creates while in public service, by taking unnecessary actions as developing excessive rules, regulations, and/or investing in good relationships with the lower-level bureaucrats. As the architect of these rules, regulations, and relationships, the regulator has inside knowledge of the system, including any loopholes and red tape that might exist. This knowledge and these connections are valuable to the firms in the industry; 'bureaucratic capital' therefore enables the bureaucrat to cash in later thereon, after exiting the public sector and passing the revolving door. These actions are all lawful and valuable for the regulator in the future, but they are highly unethical.

The formation of 'bureaucratic capital' explains the prevalence of the revolving door phenomenon in the developed world, where corruption is seldom, but unethical behavior prevails. If firms would be all equal, the creation of 'bureaucratic capital' would lead to rentseeking waste, as all firms are treated equally, and all firms finally choose the same level of 'revolvers' and bureaucratic capital.

In our model, firms are not equal in their capacities to accumulate bureaucratic capital, due to capital markets' imperfections. Big companies can afford to hire many revolvers and benefit from their 'bureaucratic capital' while small firms in the same sector cannot afford this strategy. Consequently, there is disparity in the levels of bureaucratic capital appropriated by big and small firms respectively, leading to inequality of influence and inequality in profits.

In the second part of the paper, we test this prediction. To do so, we first study the correlation between a firm's size and its stock of bureaucratic capital using data on the revolving door in the US commercial banking sector. Our findings support that big banks accumulate in average higher amounts of bureaucratic capital. ${ }^{2}$

Our other findings are that influential revolvers, i.e., revolvers from key regulatory agencies, or revolvers with longer experience in the public sector are more likely to be hired by the top five banks. Conversely, the executives of the top five banks are more likely to be hired by key regulatory agencies, or to obtain influential positions in the public sector after leaving the private sector.

\footnotetext{
${ }^{2}$ While the stock of bureaucratic capital is proxied by four different series: the number of revolvers hired by firms, the influential position of these revolvers, the number of movements between public and private offices, and the number of years of public sector experience brought by revolvers to firms.
} 
We then develop indices of the inequality of influence resulting from the disparate allocation of bureaucratic capital among banks. ${ }^{3}$ The first index is the Sectoral Revolving Door Index (SRDI), a normalized Herfindahl index that measures the concentration of bureaucratic capital among firms in the same sector. The second one, the ratio index (RI), is a ratio of the bureaucratic capital between top- 5 firms and the others.

Our indices do not measure all of the negative effects of the revolving door; they specifically focus on the differences between firms hiring many former regulators, and those without revolvers. In other words, this paper focuses on the disparity between connected and less connected firms stemming from the revolving door phenomenon.

We show that banks in the top quintile concentrate $80 \%$ of all the movements of revolvers between public agencies and private offices. Moreover, the top four banks -Goldman Sachs, JPMorgan, Citigroup, and Bank of America -- concentrate 75\% of the total "stock" of revolvers. Counting in terms of years of revolvers' public sector experience, Goldman has accumulated 698 years of revolvers' public sector experience. So, indeed, there is inequality of influence between financial firms.

The paper is divided into six parts. In the next section, we present the related literature. In Part III, we present the model. In Part IV, we perform an empirical analysis of bureaucratic capital allocation among firms in the US banking sector. In Part V, we present indices of the inequality of influence in the US banking sector. Part VI concludes.

\section{The literature}

This paper focuses on the distortions in the economy stemming from differences in the numbers of revolvers between firms in the same sector. Therefore, in what follow, we present the empirical literature on the gap between connected and unconnected firms, which mainly focuses on productivity, public procurement, access to finance and tax exemptions. ${ }^{4}$

\footnotetext{
${ }^{3}$ Hellman and Kaufman, (2004) also focus on general inequality of influence, and they use a questionnaire to analyze differences between countries. Since we focus on inequality of influence stemming from the revolving door, our indices are based on data on revolvers' career paths.

${ }^{4}$ There is also a literature on political connections and its effects on the economy which is not directly connected to our research. See in particular, Rajan and Zingales, (1998); Andvig, (2006); Faccio, (2006); Cingano and Pinotti, (2013); Kramarz and Thesmar, (2013); Luechinger and Moser, (2014); and De Haan and Veltrop, (2014).
} 


\section{Productivity}

The big picture of the very diverse literature on this topic can be summarized by stating that connected firms are not more productive than those less connected, but they overpay and earn higher profits. Cingano and Pinotti (2013), using a sample of Italian firms, have shown that corporate appointments of local politicians do not increase firms' productivity. Kramarz and Thesmar (2013), and Bertrand et al. (2006) show that French firms which are stateconnected via their CEOs and directors, tend to overpay them, are less likely to fire them if they underperform, are associated with poorer accounting performances and excessive employment rates, and make larger and worse acquisitions.

In the same flavor, Slinko et al. (2005) find that connected Russian firms adversely affect the performance of small and not connected firms, by letting administrations to create excessive regulation and by diverting government spending. By contrast, they find that nonconnected firms invest more and are more productive in regions where the concentration of firms' connections is lower.

\section{Public procurement, access to finance and tax exemptions}

The literature emphasizes that the revolving door leads to bias in the public procurement process. Indeed, Goldman et al. (2013) show that, following the 1994 House and Senate election, the presence of former politicians affiliated to the winning political party at the boards of U.S companies increases the total value of awarded public procurement contracts. In a similar vein, Cingano and Pinotti (2013) show that corporate appointments of local Italian politicians shift public demand toward connected firms, especially in regions with high public expenditures and high corruption, and that this shift reduces public good provision by $20 \%$.

Regarding the access to finance, the literature emphasizes that firms hiring 'revolvers' are associated with preferential access to finance (Khwaja and Mian, 2005; Boubakri et al, 2012) and are more likely to be bailed out after financial distress (Faccio et al., 2006). Faccio (2010) also show that state-connected firms pay lower tax than other firms. ${ }^{5}$

Slinko et al. (2005) illustrate the legislative power of connected firms in Russia by detailing the budget law of Kamchatskaya Oblast of 2001, which provides large financial support to a single state-connected firm (Akros) but not to its unconnected competitors. In

\footnotetext{
${ }^{5}$ Moreover, Johnson and Mitton (2003) show that Malaysian firms personally tied to the executive have preferred access to subsidies. Adikari et al. (2006) find similar evidences in Indonesia.
} 
their attempt to measure the concentration of the political power of Russian firms, they show that around $41 \%$ of firms in their sample benefit from legislation biased in their favor. Moreover they show that state-connected firms in Russia are allowed to accumulate more arrears in tax, and higher wage payments than their non-connected counterparts.

In summary, the literature corroborates that, compared to their non-connected counterparts, state-connected firms through the revolving door are less likely to be productive, while they are more likely to shape laws and regulations to divert state resources to their own benefits. The revolving door also affects benefits from government allocations. Country-level empirical studies suggest that firms engaged in the revolving door are more likely to use their influence so as to benefit from tax exemption and subsidy allowance. Building on this literature, we present a small model and indices which intend to proxy the extent of 'inequality of influence' by revolving door movements.

\section{The Model}

\section{Introduction}

The revolving door permits the passage of the regulators from the public service to the private one. This model focuses on the levels of revolving door movements accumulated by firms, which take place due to the bureaucratic capital accumulated by the bureaucrats.

As explained above, 'bureaucratic capital' is a specific capital accumulated by regulators during public office, in the form of networking, red-tape creation, and so on. The regulator develops them since this knowledge and these connections are valuable to the firm in the very industry she has regulated. Firms are better off hiring former regulators due to the bureaucratic capital the latter have accumulated, and thus, once having left the public service, the regulator will join the firm, cashing on this bureaucratic capital.

The standard model of bureaucratic capital, in a general equilibrium context à la Romer, enables explaining why homogenous firms will accept to pay rents for hiring a previous regulator, and this without implying any capture or wrong doing. ${ }^{6}$ In this paper, the focus is on differences between firms related to the amount of bureaucratic capital acquired. In other words, this model analyzes why bureaucratic capital may be concentrated among few firms,

\footnotetext{
${ }^{6}$ See Romer (1990), and Brezis (2017).
} 
and stresses the conditions under which the revolving door generates distortions in the economy.

The model assumes that a specific sector of the economy produces intermediate-goods by firms which have some monopolistic power (as in Romer, 1990), and that are thus regulated. Having said this, not all firms are similar due to credit markets' imperfections. Some of the firms face credit constraint, and/or higher interest rates because they are small. In this model, we analyze both types of credit imperfections: (i) differences in cost of capital and (ii) credit constraint, since these are the two most frequent credit market imperfections facing firms. We introduce both imperfections in the model, so that we can analyze each of them.

In this market, the supply of bureaucratic capital is determined by the regulators, while the demand is determined by the firms. Before presenting the demand for bureaucratic capital by the firms, we begin with the supply of bureaucratic capital which is determined by the regulators.

\section{The supply of bureaucratic capital by the regulator}

This paper focuses on a top agency regulator which works first as a regulator. Then, in the second period of her life, she can either being retired or invited to work in a company she has regulated.

During her time in office, the regulator regulates, but at the same time, she creates bureaucratic capital. The bureaucratic capital is all the unnecessary regulations and connections she is developing. One unit of bureaucratic capital can be understood as one piece of regulation, or personal connection. The regulator decides the optimal amount of overregulation she wants to develop, that will cost her effort, but that will permit her to get a higher income in the future.

The structure of the model is simple. During her term as a regulator for $T$ years, each year, she acquires bureaucratic capital (BC) of size $h_{i}$, which costs her effort, each year, of size $E_{i}$ in monetary terms. These costs are mainly of the form of investing in networks, creating redtape, building influence, accumulating knowledge of regulations, since these actions requires efforts. ${ }^{7}$

The amount of BC created by $E_{i}$ units of effort per year, while working as regulator, is monotonically increasing and concave in the total amount of effort expended during that year,

\footnotetext{
${ }^{7}$ These costs may also encompass ethical costs and social stigma.
} 
and is given by $h(E)$, with $\partial h / \partial E>0$, and $\partial^{2} h / \partial E^{2}<0$. This rate of accumulation is constant over the regulator's term, so that, at the end of the term, the total amount of bureaucratic capital created by this regulator is $H(E, T)=T h(E)$.

We assume a specific form of: $h_{i}\left(E_{i}\right)=\left[(1+\gamma) E_{i}\right]^{1 / 1+\gamma} \quad \gamma>0$. In consequence, the level of $\mathrm{BC}$, as a function of the amount of effort $E$ invested by the regulator $i$, the same for all bureaucrats, takes the form: ${ }^{8}$

$$
H_{i}\left(E_{i}\right)=T\left[(1+\gamma) E_{i}\right]^{1 / 1+\gamma} \quad \gamma>0,
$$

where $\gamma$ represents the institutional constraints over BC creation during public office.

After leaving her job as regulator, the bureaucrat works for a period of length $\tau$ in the industry that she regulated. She receives in top of her "regular" salary, a rent related to the bureaucratic capital $H_{i}$ she has accumulated.

The regulator maximizes her lifetime income which consists of (i) earnings which are not related to the creation of $\mathrm{BC}$, denoted $\Omega$, and (ii) of income related to the creation of $\mathrm{BC}$, which equals to the net income she gets when having entered the industry, after passing the revolving door. She will be able to sell her bureaucratic capital, $H_{i}$ at price $q$ for a number of years $\tau$ so that her total income is:

$$
V_{i}=\Omega-T E_{i}+\tau q H_{i}\left(E_{i}\right)
$$

Equation (2) can be rewritten as a function only of the level of BC, by substituting $E_{i}$ from equation (1). We get:

$$
V_{i}=\Omega-\frac{H_{i}^{1+\gamma}}{(1+\gamma) T^{\gamma}}+\tau q H_{i}
$$

From the point of view of the bureaucrat, there is an optimal level of bureaucratic power $\hat{H}$ which maximizes her income - equation (3) and is:

\footnotetext{
${ }^{8}$ We are aware that for some bureaucrats, who are either more social, or with less "ethical values", it is easier to either create connection with other people, or create redundant regulations. For purpose of simplicity, we assume that bureaucrats have the same "production" function of bureaucratic capital, and that these social factors are not linked to ability, since removing this assumption does not affect the results.
} 


$$
\hat{H}_{i}=T(\tau q)^{1 / \gamma}
$$

Equation (4) describes the "supply" function of BC by the regulator as an increasing function of the price $q$. The numbers of years working in the public agency, as well as in the private sector have both a positive effect on the amount of bureaucratic capital. We now turn to discuss the behavior of the firms and its demand for $\mathrm{BC}$.

\section{The demand for bureaucratic capital}

The sector we describe is composed of entrepreneurs, who run intermediate-goods firms in a monopolistic competitive environment. ${ }^{9}$ These intermediate goods are necessary to produce a final good. There are $\mathrm{N}$ firms but not equal: some are big, and therefore their cost of capital is lower than small firms which pay higher cost of capital and can also be credit constrained. The number of big, established and unconstrained firms is $n_{u}$, and the number of small and credit constrained firms is $n_{c}$, respectively producing the intermediate goods $x_{u}$ and $x_{c}$.

These intermediate goods enter the production of a final good $\mathrm{Y}$ in the following form (based on Romer, 1990):

$$
Y=L_{y}^{1-\alpha}\left(\sum_{0}^{n_{u}} x_{u}^{\alpha}+\sum_{0}^{n_{c}} x_{c}^{\alpha}\right) \quad \alpha>0
$$

where $\mathrm{Y}$ is the output; and $L_{y}$ the workers in the economy producing the final good; $x_{u}$ and $x_{c}$ are the intermediate goods used in the production of $\mathrm{Y}$.

While the intermediate-goods sector consists of monopolistic firms, the final good is produced in a perfect competitive environment. The firms involved in producing $\mathrm{Y}$ are maximizing profits:

$$
\operatorname{Max}_{y}^{1-\alpha}\left(\sum_{0}^{n_{u}} x_{u}^{\alpha}+\sum_{0}^{n_{c}} x_{c}^{\alpha}\right)-w_{y} L_{y}-\sum_{0}^{n_{u}} p_{u} x_{u}-\sum_{0}^{n_{c}} p_{c} x_{c}
$$

where $w_{y}$ are the wages paid for labor in sector $\mathrm{Y}$, and $p_{u}$ and $p_{c}$ are the prices of the intermediate goods $x_{u}$ and $x_{c}$. From the profit maximization in the production sector, we get:

$$
p_{u}=\alpha L_{y}^{1-\alpha} x_{u}^{\alpha-1} \quad \text { for all } u \in\left[0, n_{u}\right]
$$

\footnotetext{
${ }^{9}$ The basic model is based on Romer (1990) and Brezis (2017).
} 


$$
p_{c}=\alpha L_{y}^{1-\alpha} x_{c}^{\alpha-1} \text { for all } c \in\left[0, n_{c}\right]
$$

We focus on the production of the intermediate goods, $x_{u}$ and $x_{c}$. Following Romer (1990) and Brezis (2017), we assume that these firms are producing their goods using capital $\mathrm{k}$. But it is not the only factor affecting production: the amount of $\mathrm{BC}$ is positively affecting the output of the firms. Indeed, the level of BC accumulated by the regulator which is hired by the firm positively affects output.

However, if all similar firms have the same amount of $\mathrm{BC}$, then $\mathrm{BC}$ is useless for the firm. ${ }^{10}$ This assumption stems from the rent-seeking arguments according to which the revolving door does not increase production through improved productivity but through rentseeking. If $\mathrm{BC}$ was a productivity factor, it would increase firm $j$ 's production, whatever the stock of BC accumulated by its competitors. The rent seeking hypothesis comes from the basic idea that, in a given sector, if a firm is as influent as its competitors, then using influence to increase production is useless. Therefore, although having hired a bureaucrat may bring an advantage over other firms from the firm $j$ point of view, it is pure waste from a social point of view.

Since there are constrained as well as unconstrained firms, the element entering the production function should be either $H_{u} / \bar{H}$ for the unconstrained firms, or $H_{c} / \bar{H}$ for the constrained ones, where $H_{u}$ and $H_{c}$ are the level of BC demanded by unconstrained and constrained firms respectively; $\bar{H}_{u}$ and $\bar{H}_{c}$ are the average level of $\mathrm{BC}$ owned by the other unconstrained and constrained firms respectively; and $\bar{H}$ is a weighted average of $\bar{H}_{u}$ and $\bar{H}_{c}$. For sake of simplicity, we choose a linear function of these elements, so that the solution of the model is tractable. In consequence, the output of the firms is described in the following way:

$$
\begin{array}{ll}
x_{u}=\left[k_{u}+\left(\frac{\bar{H}_{u}}{\bar{H}_{c}}\right)^{\mu}\right]\left(\frac{H_{u}}{\bar{H}_{u}}\right)^{\phi} & \phi>0 \mu>0 \\
x_{c}=\left[k_{c}+\left(\frac{\bar{H}_{c}}{\bar{H}_{u}}\right)^{\mu}\right]\left(\frac{H_{c}}{\bar{H}_{c}}\right)^{\phi} & \phi>0 \mu>0
\end{array}
$$

where $H_{u}$ and $H_{c}$ are the level of $\mathrm{BC}$ demanded by unconstrained and constrained firms respectively; $\bar{H}_{u}$ and $\bar{H}_{c}$ are the average level of $\mathrm{BC}$ owned by the other unconstrained and

\footnotetext{
${ }^{10}$ This formulation is quite in use in models with monopolistic competition, as for instance the Neo-Keynesians models with price setting and monopolistic competition (see Blanchard and Kyotaki, 1987).
} 
constrained firms respectively. In other words, we divide the total rent seeking effect in two elements: the first one is the amount of bureaucratic capital of the firm relative to the amount in his own group, and also the relative amount of its group compared to the other one. In what follows, we respectively detail profit maximization by unconstrained and constrained firms.

\section{The unconstrained firms}

All firms maximize profits. Let us analyze first the unconstrained firms producing $x_{u}$. The profit maximization for an intermediate financial firm $u$ is:

$$
\operatorname{Max} \pi_{u}=p_{u}\left(x_{u}\right) x_{u}-r k_{u}-q H_{u}
$$

where $r$ is the cost of capital $k_{u}$; and $q$ the cost of BC. $q H_{u}$ is the remuneration related to $\mathrm{BC}$ obtained by the bureaucrat for being hired by the firm. Each firm maximizes profits by finding the optimal amount of factors of production. Note that equation (11) can be rewritten in the following way:

$$
\operatorname{Max} \pi_{u}=p_{u}\left(x_{u}\right) x_{u}-r\left[x_{u}\left(\frac{H_{u}}{\bar{H}_{u}}\right)^{-\phi}-\left(\frac{\bar{H}_{u}}{\bar{H}_{c}}\right)^{\mu}\right]-q H_{u}
$$

where $p_{u}$ is given by equation (7). Since the business elite are monopolists who see the price of their good as negatively related to the demand, the two first-order conditions for maximizing profits are:

$$
\begin{aligned}
& p_{u}^{\prime}\left(x_{u}\right) x_{u}+p_{u}\left(x_{u}\right)-r\left(\frac{H_{u}}{\bar{H}_{u}}\right)^{-\phi}=0 \\
& q \bar{H}_{u}=\phi r x_{u}\left(\frac{H_{u}}{\bar{H}_{u}}\right)^{-\phi-1}
\end{aligned}
$$

From equation (7), we note that the demand elasticity of $p_{u}\left(x_{u}\right)$ is equal to $\alpha-1$. Substituting into equations (13) and (14), in a symmetric equilibrium where all $H_{u}$ are the same, we get:

$$
\begin{aligned}
& p_{u}=\frac{1}{\alpha} r \\
& H_{u}=\bar{H}_{u}=\frac{\phi r x_{u}}{q}=D_{u}
\end{aligned}
$$




\section{The constrained firms}

Now we turn to analyze the small firms. These firms are affected by their size, due to credit markets imperfection which can take two different forms. First the cost of capital, $r$ is higher for these small firms, and we assume that: $r_{c}=\beta r \quad \beta \geq 1$. When $\beta$ is equal to 1, this form of imperfection is void.

The second type of imperfection faced by the firms is that there is some credit constraint. While the firm is usually not constrained on the amount of credit it can borrow to pay for the capital necessary for production, we assume that these firms do not get extra-credit for overheads. Therefore, there is some credit constraint on the overhead paid to the exregulators.

In consequence, the profit maximization for an intermediate financial firm constrained is therefore:

$$
\begin{gathered}
\operatorname{Max} \pi_{c}=p_{c}\left(x_{c}\right) x_{c}-r_{c} k_{c}-q H_{c} \\
\text { s.t. } q H_{c} \leq M
\end{gathered}
$$

As above, we substitute $k_{c}$ and the Lagrangian equation is:

$$
\operatorname{Max} L=p_{c}\left(x_{c}\right) x_{c}-r_{c}\left[x_{c}\left(\frac{H_{c}}{\bar{H}_{c}}\right)^{-\phi}-\left(\frac{\bar{H}_{c}}{\bar{H}_{u}}\right)^{\mu}\right]-q H_{c}+\lambda\left[M-q H_{c}\right]
$$

The two first-order conditions for maximizing profits of the Lagrangian are:

$$
\begin{aligned}
& p_{c}^{\prime}\left(x_{c}\right) x_{c}+p_{c}\left(x_{c}\right)-r_{c}\left(\frac{H_{c}}{\bar{H}_{c}}\right)^{-\phi}=0 \\
& -q \bar{H}_{i}+\phi r_{c} x_{i}\left(\frac{H_{i}}{\bar{H}_{i}}\right)^{-\phi-1}=\lambda H_{i}^{-\phi-1}
\end{aligned}
$$

So that:

$$
p_{c}=\frac{\beta r}{\alpha}
$$

and the demand function for $\mathrm{H}$ is:

$$
H_{c}=\bar{H}_{c}=\frac{\phi r_{c} x_{c}}{(1+\lambda) q}=D_{c}
$$


In appendix A, we show that the demand for constrained and unconstrained firms, equations (16) and (22), can be rewritten in the following form:

$$
\begin{aligned}
& H_{c}=\bar{H}_{c}=\frac{\phi r K \delta}{(1+\lambda) n q}=D_{c} \quad \text { where } \delta=\beta^{\alpha / \alpha-1} \leq 1 \\
& H_{u}=\bar{H}_{u}=\frac{\phi r K}{n q}=D_{u}
\end{aligned}
$$

where $\quad n=n_{u}+n_{c} \beta^{1 / \alpha-1}$

Remark that the ratio of $\mathrm{BC}$ in both sub-sectors is:

$$
\frac{H_{c}}{H_{u}}=\frac{\delta}{1+\lambda}<1 \quad \text { where } \delta=\beta^{\alpha / \alpha-1} \leq 1
$$

Equations (23) and (24) represent the demand for BC, as a decreasing function of $\mathrm{q}$, for both types of firms, as represented in figure 1. For big firms without credit constraint, the equilibrium bureaucratic capital is $H_{1}{ }^{*}$, while for constrained firms the equilibrium is given by $H_{2}{ }^{*}$. The ratio of these two $\mathrm{BC}$ is given by equation (25). In consequence, the $D_{c}$ function of constrained firms is at the left-hand side of the $D_{u}$ function for unconstrained firms; and the equilibrium for constrained firms $\mathrm{H}_{2}{ }^{*}$ is lower than the equilibrium for unconstrained firms $H_{1}{ }^{*}$, when both types of credit imperfections affect the ratio.

Moreover, substituting prices and quantities into the profits, we get:

$$
\begin{aligned}
& \pi_{u}=\frac{r K}{n}\left[\frac{1}{\alpha}-1-\varphi\right]+\frac{r(1+\lambda)^{\mu}}{\delta^{\mu}} \\
& \pi_{c}=\frac{r K \beta^{\alpha / \alpha-1}}{n}\left[\frac{1}{\alpha}-1-\frac{\phi}{1+\lambda}\right]+\frac{r \beta \delta^{\mu}}{(1+\lambda)^{\mu}}
\end{aligned}
$$

We therefore get the following proposition: 


\section{Proposition}

a. The amount of bureaucratic capital of constrained firms is lower than the amount for unconstrained firms, and the ratio is presented in equation (25).

b. Through bureaucratic capital accumulation, big and unconstrained firms maintain their profits at a higher level than small firms.

\section{[Figure 1]}

The proposition holds for both types of credit markets imperfections: credit constraint and different interest rates. It is sufficient that one of these imperfections holds to get this difference in the behavior of firms.

To conclude, this model of bureaucratic capital emphasized two main facts. The first one is that differences between firms due to their sizes and costs of capital lead to major differences in their behavior. Big firms can hire many revolvers and get state connected, while small firms cannot hire many revolvers and in consequence they are less connected, if at all.

These differences in the revolving door lead to differences in profits between them. In other words, big firms or too-big-to-fail firms maintain their dominant position and their market power via the revolving door, and not through efficient decisions. Therefore, the revolving door process leads to distortions in the economy.

The next section is an empirical analysis of bureaucratic capital allocation among big and small firms. Then, we measure the inequality of influence resulting from this allocation, by proposing indices highlighting differences in the levels bureaucratic capital accumulation between firms from the same sector.

\section{Empirical analysis}

Our theoretical model stresses the existence of two different equilibria of bureaucratic capital allocation: one high-level equilibrium where the biggest firms accumulate most of the bureaucratic capital, and one low-level equilibrium where bureaucratic capital accumulation by smaller firm is limited. To test these predictions, we gathered data on the career path of regulators (hereafter called revolvers) that undertook public-to-private or private-to-public sector movements between the top 20 US commercial banks and US regulatory agencies. 
Building on this information, we constructed four proxies of the stock of bureaucratic capital accumulated by banks:

a. Proxy 1 "revolvers": the number of revolvers that have been hired by banks.

b. Proxy 2 "influence": influence is proxied by,

i. the number of revolvers who got influential position in the public sector; or

ii. the number of revolvers who have worked in key regulatory agencies.

c. Proxy 3 "movements": the cumulated number of public-to-private sector and privateto-public sector revolving door movements undertaken by revolvers hired by banks.

d. Proxy 4 "experience": the total number of years of experience in the public sector accumulated by revolvers hired by banks.

Appendix B provides information on the data collection and treatment processes. The data will permit us to supply empirical evidences related to our model.

\section{Insights into the bureaucratic capital allocation and origin}

We have identified 304 revolvers who have been hired by at least one of the 20 biggest US commercial banks and who have undertaken 384 revolving door movements between public and private positions, from 1933 to $2015 .^{11}$

Figure 2 represents the distributions of the numbers of revolvers and cumulated years of the revolvers in public office in the various banks. The left-hand side figure depicts the distribution of revolving door movements among commercial banks. Four banks: Goldman Sachs, JP Morgan, Citigroup and Bank of America concentrate $75 \%$ of the stock of revolvers, and $78 \%$ of the stock of years of public sector experience brought by revolvers. Appendix C provides more details on how our bureaucratic capital is distributed among firms and public agencies, according to our four proxies of $\mathrm{BC}$.

\section{[Figure 2]}

\footnotetext{
${ }^{11}$ The oldest revolving door movement we documented involves Sidney J. Weinberg, a.k.a "Mr. Wall Street", who was former executive of Goldman Sachs from 1927 to 1969, and who was counselor at the White House from 1933 to 1969. He notably advised Presidents Roosevelt, Eisenhower, and Johnson. The data collected might not be fully exhaustive because of a lesser availability of information on past revolving door movements. However, they are representative of the revolving door process in the sample. See appendix B.
} 
Among the 304 revolvers identified, 187 revolvers have worked in the nine key agencies directly related to the regulation of the financial sector (e.g. the SEC, the Fed), or with influence over it (e.g. the White House, the Congress' Bank and Finance Committees). These regulatory agencies are the following, by decreasing order of revolver provision: the Federal System (53 revolvers); the Treasury (40); the White House (26); the Congress Bank and Finance Committees (24); the US Trade Representative (10); the Security Exchange Commission (13); Intelligence Agencies (10); the Federal Deposit Insurance Corporation (FDIC) (8); and the Commodity Future Trading Commission (CFTC) (3). The remaining 117 revolvers have worked in agencies not directly related to financial matters such as the Secretariat of Defense, the Secretariat of State, embassies, governorates, congressmen offices, and so on. Figure 3 represents the distribution of bureaucratic capital according to its agency of origin.

\section{[Figure 3]}

\section{Bureaucratic capital and firm size}

We now check whether big firms are associated with a greater stock of bureaucratic capital than smaller firms. Table 1 reports the mean-comparison t-test of our four bureaucratic capital variables between the top 5 banks and the other ones. We present the Top 5 banks either ranked by profit order or by total revenue. T-tests show that we can reject the null hypothesis of equal mean between top 5 and other banks against the alternative that the mean of bureaucratic capital stock is lower in smaller bank than in big banks. ${ }^{12}$ Therefore, this first evidence supports that big banks accumulate in average higher amounts of bureaucratic capital. P-values are lower when top 5 banks are identified according to their total revenue (1$2 \%$ significant) rather than their profits $(2-4 \%)$.

\section{[Table 1]}

Figures 4 and 5 represent graphically the partial correlation between our four proxies of bureaucratic capital and the size of banks in 2015. Size is measured either by banks' profits as in figure 4, or by total revenue as in figure 5. Profits are found to be strongly and positively correlated with firms' stock of bureaucratic capital, but more particularly correlated with the number of influential revolvers and the number of years of public office experience

\footnotetext{
${ }^{12}$ Moreover, we cannot reject the null of equal mean against the alternative that the mean of bureaucratic capital stock is higher in smaller banks than in big banks.
} 
accumulated by banks. This positive relationship gets stronger, as evidenced by the higher Rsquared, when firm's size is approximated by its total revenue.

\section{[Figures 4 \& 5]}

All in all, this first empirical evidence strongly supports the proposition of our model according to which big firms with lower liquidity constraint accumulate a greater stock of bureaucratic capital. In support of this preliminary evidence, we now present a multivariate analysis of bureaucratic capital allocation. First we start by analyzing bureaucratic capital allocation among banks by focusing on public-to-private sector movements. Then, we focus on private-to-public movements and test whether big firms accumulate bureaucratic capital by sending their staff to key positions in the public sector.

3. Multivariate analysis of bureaucratic capital allocation: evidence from public-to-private revolving door movements.

One important prediction of our model is that unconstrained (or too-big-too-fail) firms are the principal destination of bureaucratic capital allocation, as in equation (25). In consequence, regulators completing their term in public agency with a lengthy experience in the public sector, leaving either key regulatory agencies or an influential position in public office, are more likely to be hired by big firms. ${ }^{13}$ Therefore, a higher amount of bureaucratic capital created in public office should increase the likelihood of being hired by the biggest banks.

To test our model, we conduct a multivariate analysis of the effect of bureaucratic capital supplied by revolvers on the conditional probability of working in the top-5 banks, ranked according to their total revenue. First, we apply a logistic model to cross-section data on around 210 public-to-private revolving door movements from public agencies towards the top-20 US commercial banks, with the dependent binary variable:

$h_{\mathrm{i}}=\left\{\begin{array}{c}1 \text { if the } \mathrm{i}^{\text {th }} \text { revolver has been hired by a top } 5 \text { bank } \\ 0 \text { otherwise }\end{array}\right.$

\footnotetext{
${ }^{13}$ see Appendix B for the identification of influential position.
} 
The top-5 banks are identified according to their total revenue in 2015. The random variable $y$ takes the value one or zero, associated to the probability $\mathrm{p}_{\mathrm{i}}$ and $\left(1-\mathrm{p}_{\mathrm{i}}\right)$ respectively. We suppose that the logit of the probability $p_{i}$ is:

$$
\operatorname{Logit}\left(p_{i}\right)=X_{i}^{\prime} \beta
$$

where $\beta$ is a vector of regression coefficients and $X_{i}$ is a vector of covariates which includes proxies of bureaucratic capital and other determinants of firm size. More specifically, bureaucratic capital is either proxied by:

- Model A: using proxy $2 \mathrm{i}$, the revolver's influence ${ }^{14}$ in public office (1=influential; $0=$ not influential)

- Model B: using proxy 2ii, the revolver's experience in a key federal regulatory agency $(1=$ the revolver has worked in a key regulatory agency; $0=$ the revolver has not).

- Model C: using proxy 3, the revolver's experience in public office (in years).

We also look at the effect of various factors of bureaucratic capital depreciation:

i. The time gap (in years) between public sector exit and private sector entry. This variable is of interest since regulation on the revolving door imposing a coolingoff period between public and private offices are based on the underlying assumption of bureaucratic capital depreciation.

ii. The time laps (in years) between 2015 and the year the revolver has left public office, since it is possible that bureaucratic capital that has been created a long time ago may have lost value.

iii. The time laps between 2015 and the year the revolver has left the private bank (in years), since it is possible that bureaucratic capital that has been supplied to the bank a long time ago may have also lost value. ${ }^{15}$

Finally, we control (i) for the logarithm of the number of employees - to ensure that public regulators do not go into the top 5 banks because the latter hire more people; and (ii) for firm's long-run financial performance by including the 10 years earning-per-share annual change. Estimated marginal effects are reported in Table 2.

\footnotetext{
${ }^{14}$ see Appendix B for the identification of influential position.

15 This variable is equal to zero if the revolver is still working in the private bank.
} 
Indeed, firm's determinants of total revenue (firm's number of employees and financial performance) have the expected effect on the probability of working for the top 5 banks. But more importantly, proxies of bureaucratic capital are positively and significantly associated with the probability of being hired by a top-5 bank. It is also worth noting that the time gap between public and private office erodes bureaucratic capital, as it is found to significantly reduce the probability of being hired by a top- 5 banks in models $\mathrm{B}$ and $\mathrm{C}$, thereby giving an empirical justification to restrictions on bureaucratic capital allocation such as cooling-off periods after leaving public office.

\section{[Table 2]}

4. Multivariate analysis of bureaucratic capital allocation: evidence from private-to-public sector revolving door movements.

We now turn to examine private-to-public sector revolving door movements and test whether big banks are more likely to send their former employees either in agencies with strong regulatory powers, or to influential positions in the public sector. While our model emphasizes only how revolvers sell their $\mathrm{BC}$ after leaving public office, private-to-public sector movements are still very common and also induce inequality of influence between firms, which make them of interest for our analysis. ${ }^{16}$

We therefore conduct logit estimations of equation (28) taking $p_{i}$ as the revolver's probability of being hired in a key regulatory agency. We add to the firm-level control included in previous estimations the revolver's private sector experience (measured in years). Results are reported in Table 3 and estimates of columns stress that, disregarding their own experience in the private sector, the revolvers from the top 5 banks are more likely to be hired by key regulatory agencies (columns (1) and (2)) and to get an influential position in these agencies (columns(5) and (6)). In columns (3) and (6), we are interested in identifying which of the 5 biggest banks has the highest probability sending revolvers to positions with important regulatory power. Estimates support that revolvers from all big banks except Wells Fargo are associated with positive and significant probability of being hired in a key

\footnotetext{
${ }^{16}$ And it is also not uncommon to see private sector officers cashing in huge exit bonanza before taking public responsibilities. See for instance Samantha Lachamn, "Hillary Clinton Backs Bill That Would Ban 'Golden Parachutes' For Wall Street Bankers", The Huff, Aug 31, 2015.
} 
regulatory agency. Interestingly, revolvers from Citigroup have the greatest probability of being hired in a key regulatory agency and are the only ones having a positive and significant probability of getting an influential position in these agencies.

\section{[Table 3]}

To summarize, this section has provided evidence on these following facts: (i) Bank's stock of bureaucratic capital is strongly correlated with its size. (ii) Banks are more likely to hire revolvers which supply greater amounts of bureaucratic capital - whether measured in terms of years of public sector experience, experience in key regulatory agency, or in terms of influence. (iii) Banks are more likely to send their staff into public agencies, or positions with the larger influence over the financial sector regulation. We now turn to develop indices of the inequality of influence between firms in a specific sector.

\section{Measuring the inequality of influence}

In the previous sections we have shown that unequal allocation of bureaucratic capital and revolvers is related to dissimilar behavior and to unequal profits. In the theoretical part, the inequality of influence between firms resulting from the differences in the amount of bureaucratic capital accumulated by big and connected firms compared to small and lessconnected firms, is expressed in equation (25). It is then important to have an indicator on the concentration of bureaucratic capital, or in other words, of inequality of influence. In the next section we propose measures of the inequality of influence resulting from the concentration of bureaucratic capital among the biggest banks.

\section{Indices of the inequality of influence}

We propose two indices of the concentration of bureaucratic capital in the US commercial banking sector. The first one, denoted the Ratio-Index (RI), is the share of the amount of bureaucratic capital cumulated by banks in the top revenue quintile, in the total amount of BC cumulated by the top 20 commercial banks. The second index coined as Sectorial Revolving Door Index (SRDI) is derived from a normalized Hirschman-Herfindahl 
index formula. ${ }^{17}$ It measures the overall sector concentration of bureaucratic capital, and is computed as follow:

$$
S R D I_{S}=\frac{\sqrt{\sum_{i=1}^{N}\left(\frac{b_{i}}{B}\right)^{2}}-\sqrt{1 / N}}{1-\sqrt{1 / N}}
$$

$B$ is the total amount of bureaucratic capital (e.g. number of revolvers), $b_{i}$ is the amount of bureaucratic capital in firms $i$ and $N$ is the total number of firms in the sector $\left(N=n_{u}+n_{c}\right)$. These indices are measuring the inequality of influence, since the higher the index in sector $s$, the stronger the concentration of bureaucratic capital, the greater the inequality of influence, and so, the distortions in sector $s$.

In the following section, we measure the inequality of influence in the US banking sector by calculating these indices using our dataset on the revolving door process in the top 20 US commercial banks.

\section{The inequality of influence in the US commercial banking sector}

We proceed to the calculation of the RI and SRDI on the various proxies of bureaucratic capital stock presented above: the number of revolvers, the number of revolving door movements, and the number of years of revolvers' experience in public agencies cumulated by banks. ${ }^{18}$ Results are presented in Tables 4 and 5 .

The RI (ratio of number of revolvers in the top 5) shows that Goldman Sachs (GS), JPMorgan (JPM), Citigroup (CG), Bank of America (BofA), and (in a much lesser extent) Wells Fargo (WF) concentrate together $79 \%$ of revolvers and revolving door movements, and $82 \%$ of the total stock of years of public office experience (see Table 4 and Figure 3 ).

The three following firms in terms of total revenue by decreasing order -- Morgan Stanley, American Express, and Capital One Financial -- are moderately using the revolving

\footnotetext{
${ }^{17}$ Cracau and Duran-Lima (2016) show in which cases, this version of the normalized HH is better than the regular $\mathrm{HH}=\frac{\sum_{i=1}^{N}\left(\frac{b_{i}}{B}\right)^{2}-1 / N}{1-(1 / N)}$

${ }^{18}$ This last proxy is an interesting measure of bureaucratic capital, since the number of years spent in public agencies (T) entered equation (4), and affects the total amount of revolvers. It is however more subject to measurement errors since information on revolvers' career paths may not be fully exhaustive.
} 
door and represent around $12 \%$ of the total stock of revolvers and revolving door movements (see Appendix C). The revolving door process in the remaining sample of firms is almost nil.

Among these 20 firms, Goldman Sachs appears as the prime beneficiary of bureaucratic capital accumulation, by concentrating $27 \%$ of the total stock of revolvers and revolving door movements, $31 \%$ of the cumulated years of public office experience, i.e., 698 years among a total of 2256 years of public office experience.

Concerning the SRDI, we find out that as shown in Table 4, the SRDI is equal to 0.231 regarding the number of revolvers, and 0.237 regarding the total movements of revolvers (see appendix B). ${ }^{19}$ Taking into account the number of years worked in the agency, the concentration score raises to 0.259 .

\section{[Table 4]}

Next, we measure the concentration of revolvers among firms according to their regulatory agency of origin. Focusing on key regulatory agencies, we found a strong concentration among the "big five" of bureaucratic capital created at the White house: the SRDI rises dramatically to 0.384 and the RI indicates that $92 \%$ of White House's revolvers have worked for the big five (see Table 5). The concentration of bureaucratic capital created at the Treasury is also strong, with a SRDI equal to 0.356 and a RI of $88 \%$ for the big five (42\% for Goldman Sachs alone).

By contrast, the Federal Reserve System, which provided the greatest number of revolvers, is associated with the lowest concentration scores (SRDI of 0.238 , and the RI is "only" 74\%). Indeed, it is worth noting that regarding the revolving door from the Fed, there is more 'equality' in the system, and a greater number of small firms can also hire revolvers from this agency. This increasing equality in the distribution of the bureaucratic capital appears also in the category of "other agencies" not directly related to financial matters, as described by a SRDI equal to 0.178 (Table 5, last column).

On the other hand, we observe very high concentration patterns at the SEC, Intelligence agencies, and the CFTC -- agencies with great regulatory powers (SRDI of .43; .34; and .67). Therefore, while bureaucratic capital from these agencies is scarce, it seems highly valuable since almost all revolvers from these agencies end up in the big five.

\footnotetext{
${ }^{19}$ Increasing by $100 \%$ the total number of firms, from 20 to 40 smaller firms, and assuming that these additional firms do not get involved in the revolving door (which is consistent with the high correlation between firm size and the revolving process previously observed in figure 3) leads to a SRDI score of 0.291 applied to revolvers, and a SRDI score of 0.296, corresponding to a $25 \%$ increase in SRDI score approximatively.
} 
[Table 5]

In conclusion of this section, our indices permit to measure the inequality of influence among firms, resulting from the revolving door. Our two indices, the SRDI and the RI, emphasize the concentrated nature of the market of bureaucratic capital in the banking sector, where much of the bureaucratic capital accrue to four big banks and a small residual amount of bureaucratic capital is spread in the remaining 16 banks.

\section{Conclusion}

This paper addresses the effects of the revolving door phenomenon on the inequality of influence among firms. It shows that firms are not equal in their capacities to accumulate 'bureaucratic capital'. Big companies can afford to hire many revolvers and benefit from their bureaucratic capital, while small firms in the same sector cannot afford this strategy. This disparity and unfair competition in the numbers of revolvers and levels of bureaucratic capital are what this paper analyzes.

We first develop a theoretical model explaining how the revolving door generates inequality of influence. Therein, due to credit markets imperfections, revolvers supply bureaucratic capital mostly to a small number of large firms, enabling them to derive influence over public decision-making and to maintain their dominant positions. In fact, these differences in the revolving door lead to differences in profits between them.

In the second part of the paper, this prediction is tested on a new database tracking the revolving door process involving 304 individuals and the 20 biggest US commercial banks. We show that regulators who have created much bureaucratic capital are more likely to be hired by the top five banks after leaving public office. Conversely, the executives of the top five banks are more likely to be hired by key regulatory agencies or to obtain influential positions in the public sector after leaving the private sector.

We have also developed indices of the inequality of influence: the Ratio Index (RI) and the Sectoral Revolving Door Index (SRDI), a Herfindahl index of the sectoral concentration of the revolving door process. These indices enable measuring the concentration of influence induced by the revolving door. Our results show that the top five banks contain $80 \%$ of revolvers and revolving door movements, and $82 \%$ of the total years spent by revolvers in 
public office. Goldman Sachs appears to be the prime beneficiary of this process, containing nearly $30 \%$ of total revolvers, revolving door movements, and time in public office, thereby having accumulated 698 years of influence in public office.

These indices are therefore useful tools for assessing policies aimed at preventing bureaucratic capital concentration. They may also be helpful in raising awareness of the need for institutional safeguards against the overwhelming influence of too-big-to-fail banks over financial regulations. 


\section{Figures}

\section{Figure 1. The equilibrium of bureaucratic capital}

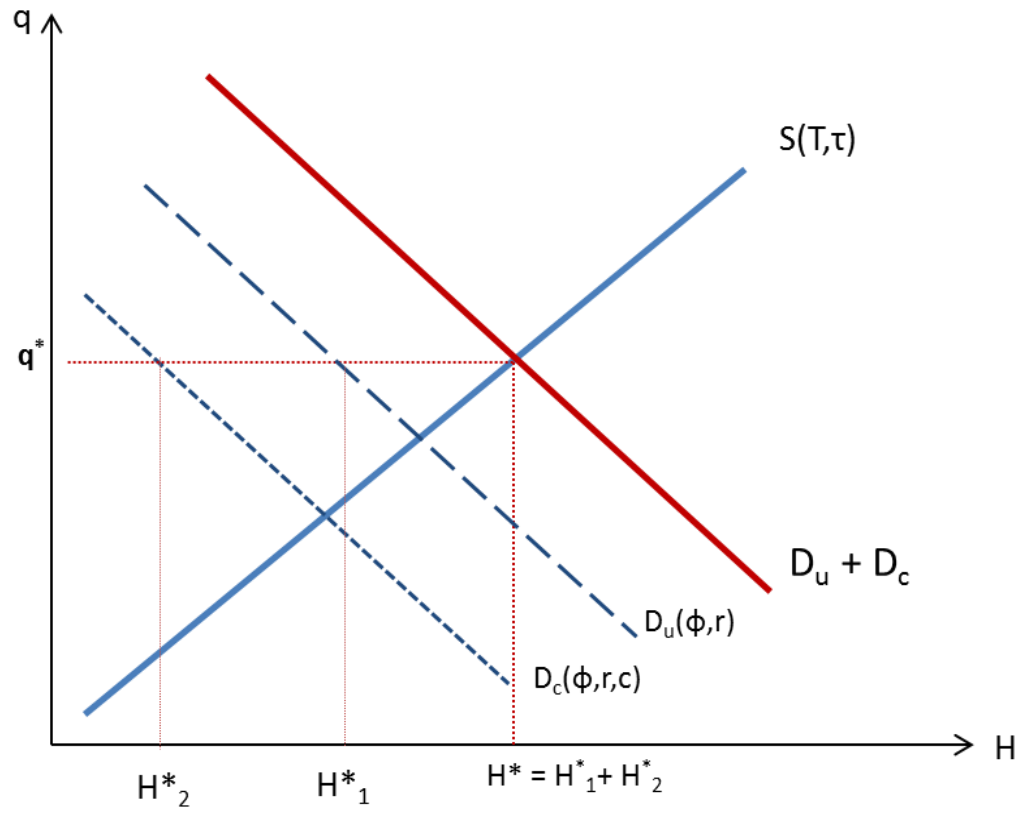

Figure 2. Sector distribution of bureaucratic capital among the top 20 commercial banks
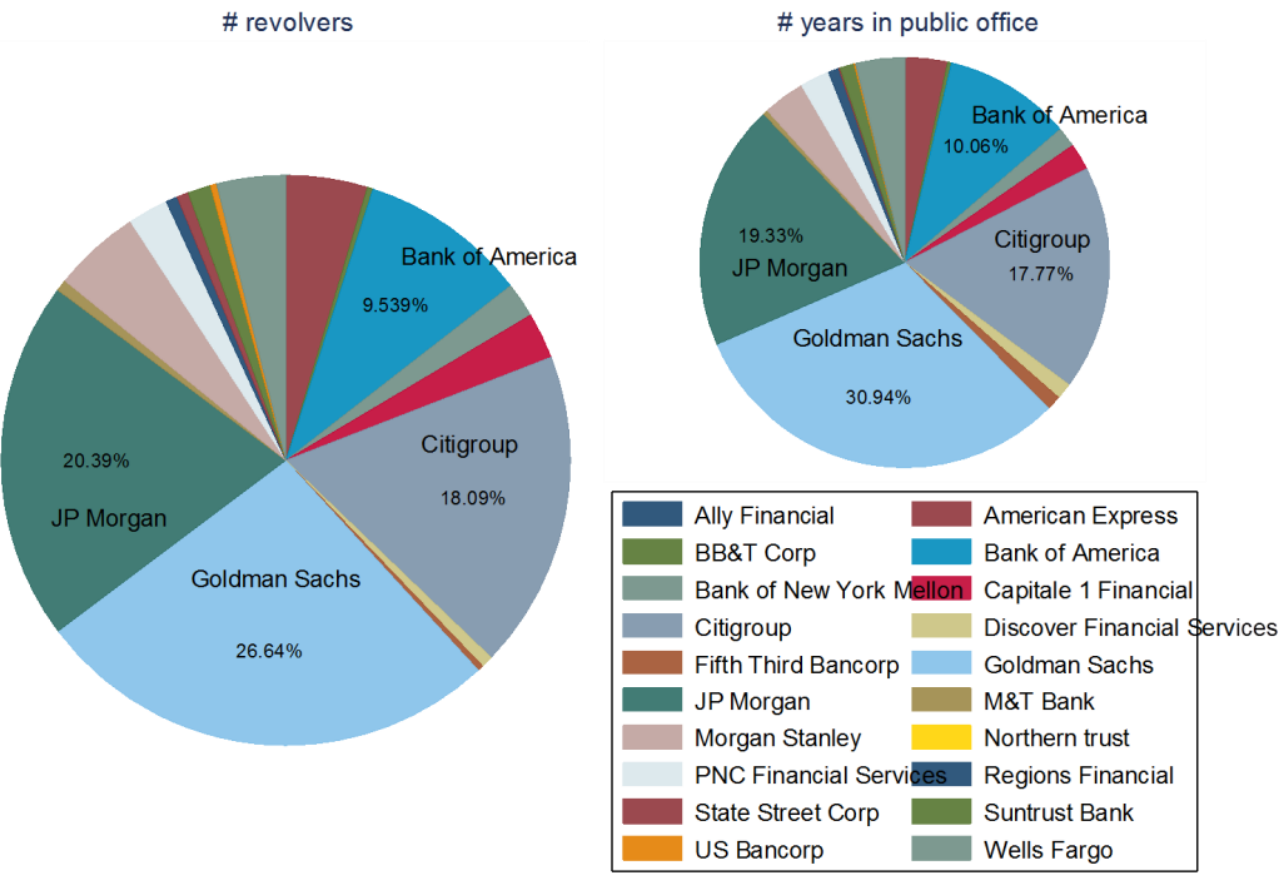


\section{Figure 3. Distribution of bureaucratic capital among public agencies}

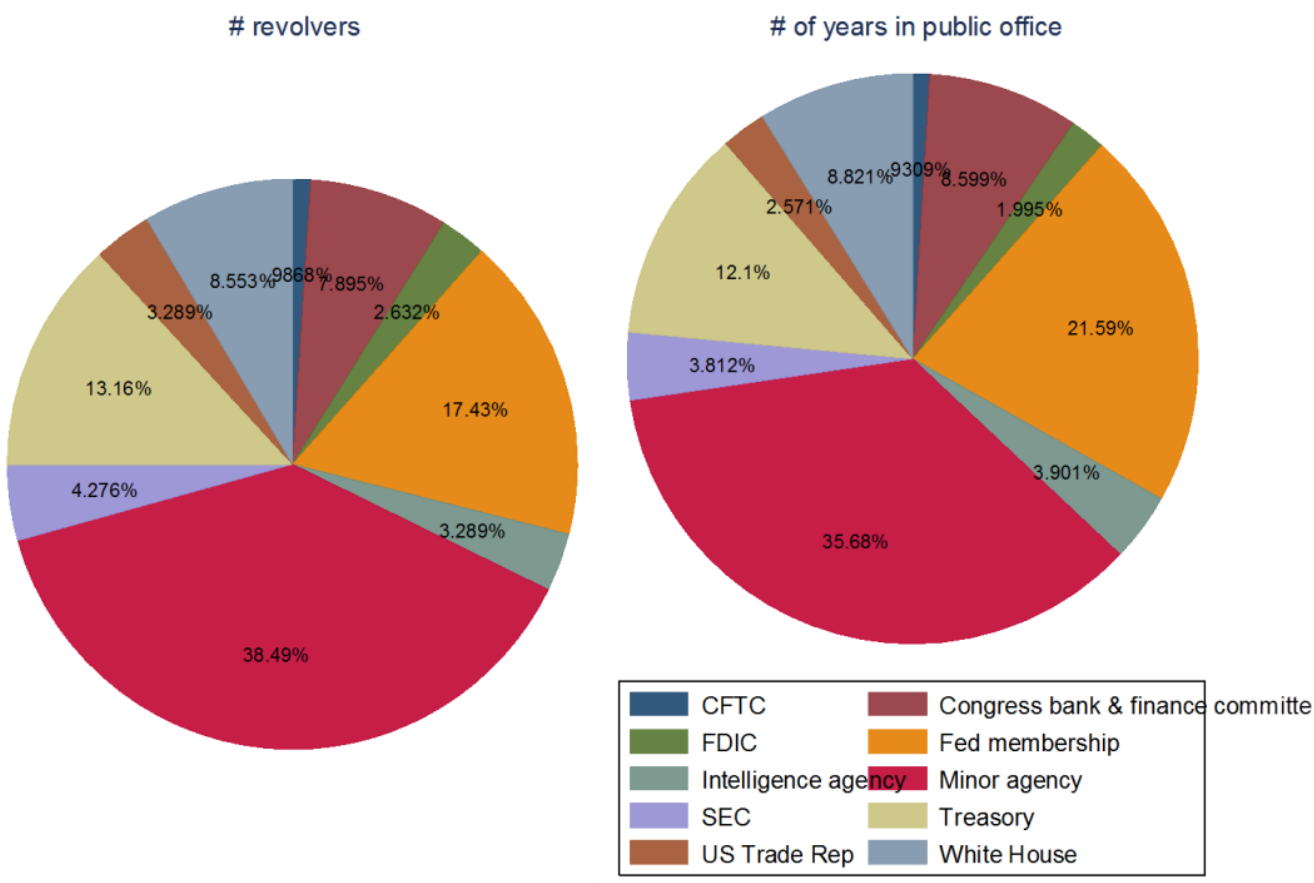

Figure 4. Bureaucratic capital and bank's profits
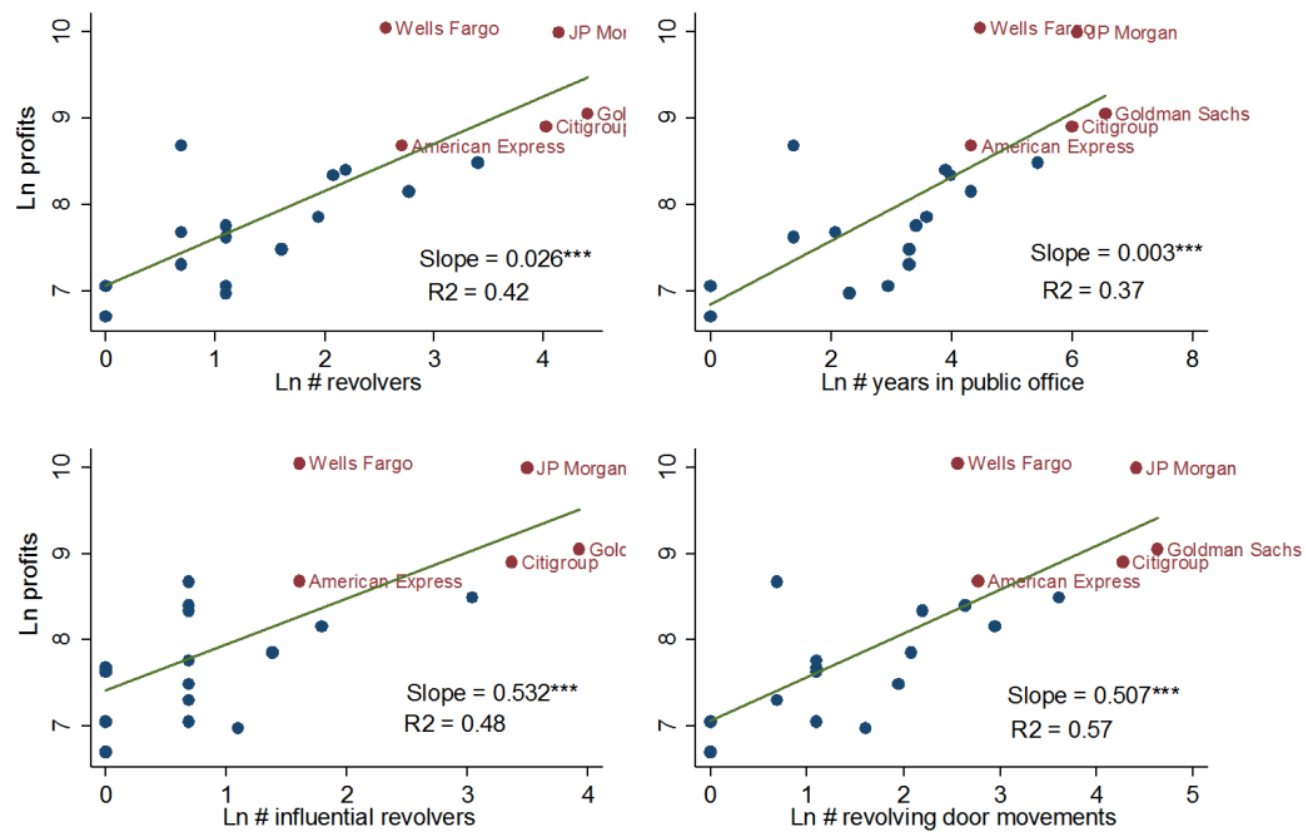

Notes: Data on firms' profit in 2015 is drawn from Fortune 500. Top 5 banks are in red. 
Figure 5. Bureaucratic capital and bank's total revenue
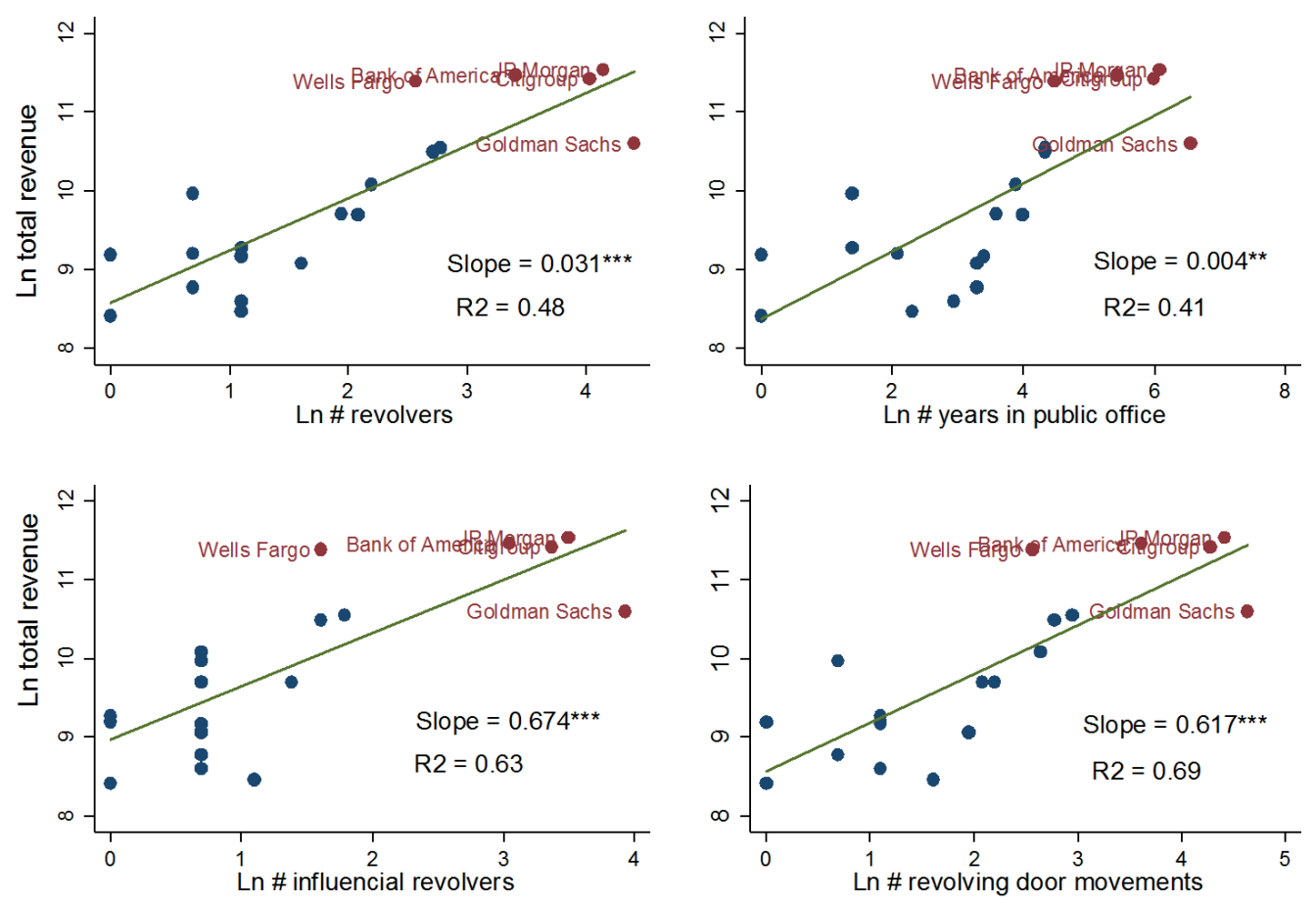

Notes: Data on firms' total revenue in 2015 is drawn from Fortune 500. Top 5 banks are in red. 


\section{Tables}

Table 1 - Mean-comparison tests.

\begin{tabular}{llllll}
\hline \hline Ho: mean(non-top 5) - mean(top5) $=0$ & $\begin{array}{l}\text { Proxy 1: } \\
\text { \# revolvers }\end{array}$ & $\begin{array}{l}\text { Proxy 2: } \\
\text { \# influential } \\
\text { revolvers }\end{array}$ & $\begin{array}{l}\text { Proxy 3: } \\
\text { \# RD movements }\end{array}$ & $\begin{array}{l}\text { Proxy 4: } \\
\text { oears in public } \\
\text { office }\end{array}$ \\
\hline Top 5 profits & Ha : $\operatorname{Pr}(\mathrm{T}<\mathrm{t})$ & 0.022 & 0.037 & 0.026 & 0.031 \\
& $\mathrm{Ha}: \operatorname{Pr}(\mathrm{T}>\mathrm{t})$ & 0.97 & 0.96 & 0.97 & 0.97 \\
\hline Top 5 revenues & Ha : $\operatorname{Pr}(\mathrm{T}<\mathrm{t})$ & 0.012 & 0.013 & 0.014 & 0.98 \\
& $\mathrm{Ha}: \operatorname{Pr}(\mathrm{T}>\mathrm{t})$ & 0.99 & 0.99 & 0.99 & \\
\hline \hline
\end{tabular}

Note: T-tests relax the hypothesis of equal variance between the top 5 and the other banks. 
Table 2 - Empirical evidence from public-to-private revolving door movements, logit estimates.

\begin{tabular}{|c|c|c|c|c|c|c|c|c|c|c|}
\hline \multirow{2}{*}{\multicolumn{2}{|c|}{ Var dep. }} & \multicolumn{9}{|c|}{ Public-to-private revolver has been hired by a top 5 commercial banks (0/1) } \\
\hline & & (1) & \multicolumn{2}{|l|}{$\begin{array}{l}(2) \\
\text { Model A }\end{array}$} & (4) & \multicolumn{2}{|l|}{ Model B } & $(10)$ & \multicolumn{2}{|l|}{$\begin{array}{l}(11) \\
\text { Model C }\end{array}$} \\
\hline \multicolumn{2}{|c|}{ Bureaucratic capital } & & & & & & & & & \\
\hline \multicolumn{2}{|c|}{ Influential revolver } & $\begin{array}{l}0.112 * * * \\
(0.039)\end{array}$ & $\begin{array}{l}0.114 * * * \\
(0.043)\end{array}$ & $\begin{array}{l}0.097 * * \\
(0.04)\end{array}$ & & & & & & \\
\hline \multicolumn{2}{|c|}{ Revolver from key fed. Agency } & & & & $\begin{array}{l}0.108 * * \\
(0.045)\end{array}$ & $\begin{array}{l}0.094 * * \\
(0.047)\end{array}$ & $\begin{array}{l}0.079 * * * \\
(0.046)\end{array}$ & & & \\
\hline \multicolumn{2}{|c|}{ Total time in pub. office } & & & & & & & $\begin{array}{l}0.007 * * * \\
(0.003)\end{array}$ & $\begin{array}{l}0.007 * * \\
(0.003)\end{array}$ & $\begin{array}{l}0.007 * * \\
(0.003)\end{array}$ \\
\hline \multicolumn{11}{|c|}{ Bureaucratic capital depreciation } \\
\hline i. & $\begin{array}{l}\text { Time gap btw public exit and } \\
\text { private sector entry }\end{array}$ & & $\begin{array}{l}-0.005^{*} \\
(0.003)\end{array}$ & $\begin{array}{l}-0.005 * * \\
(0.002)\end{array}$ & & $\begin{array}{l}-0.005^{*} \\
(0.003)\end{array}$ & $\begin{array}{l}-0.005^{* *} \\
(0.003)\end{array}$ & & $\begin{array}{l}-0.004 \\
(0.002)\end{array}$ & $\begin{array}{l}-0.004 \\
(0.002)\end{array}$ \\
\hline ii. & $\begin{array}{l}\text { Time laps since leaving public } \\
\text { office }\end{array}$ & & & $\begin{array}{l}0.001 \\
(0.002)\end{array}$ & & & $\begin{array}{l}0.002 \\
(0.002)\end{array}$ & & & $\begin{array}{l}0.002 \\
(0.002)\end{array}$ \\
\hline iii. & $\begin{array}{l}\text { Time laps since leaving private } \\
\text { office }\end{array}$ & & & $\begin{array}{l}0.006 \\
(0.004)\end{array}$ & & & $\begin{array}{l}0.007 * \\
(0.004)\end{array}$ & & & $\begin{array}{l}0.008 * \\
(0.004)\end{array}$ \\
\hline \multicolumn{11}{|c|}{ Firm size and performance } \\
\hline \multicolumn{2}{|c|}{ Ln number of employees } & $\begin{array}{l}0.162^{* * * *} \\
(0.33)\end{array}$ & $\begin{array}{l}0.163 * * * \\
(0.033)\end{array}$ & $\begin{array}{l}0.144 * * * \\
(0.034)\end{array}$ & $\begin{array}{l}0.176 * * * \\
(0.033)\end{array}$ & $\begin{array}{l}0.179 * * * \\
(0.035)\end{array}$ & $\begin{array}{l}0.156 * * * \\
(0.037)\end{array}$ & $\begin{array}{l}0.176 * * * \\
(0.32)\end{array}$ & $\begin{array}{l}0.179 * * * \\
(0.034)\end{array}$ & $\begin{array}{l}0.151 * * * \\
(0.034)\end{array}$ \\
\hline \multicolumn{2}{|c|}{10 years EPS annual change } & $\begin{array}{l}0.005 * * * \\
(0.001)\end{array}$ & $\begin{array}{l}0.005 * * * \\
(0.001)\end{array}$ & $\begin{array}{l}0.004 * * * \\
(0.001)\end{array}$ & $\begin{array}{l}0.006 * * * \\
(0.001)\end{array}$ & $\begin{array}{l}0.006 * * * \\
(0.001)\end{array}$ & $\begin{array}{l}0.005^{* * * *} \\
(0.001)\end{array}$ & $\begin{array}{l}0.006 * * * \\
(0.001)\end{array}$ & $\begin{array}{l}0.006 * * * \\
(0.001)\end{array}$ & $\begin{array}{l}0.005^{* * * *} \\
(0.001)\end{array}$ \\
\hline \multirow{2}{*}{\multicolumn{2}{|c|}{$\begin{array}{l}\text { Pseudo-R2 } \\
\text { Observations }\end{array}$}} & 0.36 & 0.37 & 0.41 & 0.33 & 0.34 & 0.38 & 0.33 & 0.34 & 0.39 \\
\hline & Observations & 214 & 207 & 206 & 218 & 207 & 206 & 209 & 205 & 204 \\
\hline
\end{tabular}

Marginal effects reported. Standard errors are presented in parentheses: * significant at 10\%,** significant at 5\%, *** significant at $1 \%$. Standard errors are robust to heteroscedasticity 
Table 3 - Empirical evidence from private-to-public revolving door movements, logit estimates.

\begin{tabular}{|c|c|c|c|c|c|c|}
\hline \multirow{2}{*}{ Var dep. } & \multirow{2}{*}{\multicolumn{3}{|c|}{$\begin{array}{c}\text { Revolver has held an influential } \\
\text { position in public agencies after leaving } \\
\text { private office }(0 / 1) \\
\text { Proxy } 2 i\end{array}$}} & \multirow{2}{*}{\multicolumn{3}{|c|}{$\begin{array}{c}\text { Revolver has worked in a key } \\
\text { regulatory agency after leaving } \\
\text { private office }(0 / 1) \\
\text { Proxy } 2 i i\end{array}$}} \\
\hline & & & & & & \\
\hline Top 5 bank dummy & $\begin{aligned} &(1) \\
& 0.342 * * * \\
&(0.103)\end{aligned}$ & $\begin{array}{r}(2) \\
0.332 * * * \\
(0.105)\end{array}$ & (3) & $\begin{array}{l}(4) \\
0.214^{*} \\
(0.113)\end{array}$ & $\begin{array}{l}(5) \\
0.238 * * \\
(0.116)\end{array}$ & (6) \\
\hline BofA dummy & & & $\begin{array}{r}0.245 \\
(0.167)\end{array}$ & & & $\begin{array}{r}0.246 * * * \\
(0.069)\end{array}$ \\
\hline Citigroup dummy & & & $\begin{array}{r}0.343 * * * \\
(0.112)\end{array}$ & & & $\begin{array}{r}0.267 * * * \\
(0.065)\end{array}$ \\
\hline JPMorgan dummy & & & $\begin{array}{r}-0.019 \\
(0.183)\end{array}$ & & & $\begin{array}{r}0.219 * * \\
(0.094)\end{array}$ \\
\hline Goldman Sachs dummy & & & $\begin{array}{r}-0.183 \\
(0.180)\end{array}$ & & & $\begin{array}{r}0.247 * * * \\
(0.075)\end{array}$ \\
\hline Wells Fargo dummy & & & -- & & & $\begin{array}{r}-0.586 * * * \\
(0.276)\end{array}$ \\
\hline Total time in private office & & $\begin{array}{r}-0.004 \\
(0.004)\end{array}$ & $\begin{array}{r}-0.004 \\
(0.004)\end{array}$ & & $\begin{array}{r}0.005 \\
(0.004)\end{array}$ & $\begin{array}{r}0.008 * * \\
(0.004)\end{array}$ \\
\hline \multicolumn{7}{|l|}{ Firm size } \\
\hline Ln number of employees & $\begin{array}{r}-0.047 \\
(0.053)\end{array}$ & $\begin{array}{r}-0.052 \\
(0.056)\end{array}$ & $\begin{array}{r}-0.001 \\
(0.056)\end{array}$ & $\begin{array}{r}-0.047 \\
(0.051)\end{array}$ & $\begin{array}{r}-0.022 \\
(0.052)\end{array}$ & $\begin{array}{r}-0.016 \\
(0.047)\end{array}$ \\
\hline $\begin{array}{l}\text { EPS annual change } 10 \\
\text { years }\end{array}$ & $\begin{array}{r}-0.008 * * \\
(0.004)\end{array}$ & $\begin{array}{r}-0.008 * * \\
(0.004)\end{array}$ & $\begin{array}{r}-0.007 * \\
(0.004)\end{array}$ & $\begin{array}{r}-0.002 \\
(0.003)\end{array}$ & $\begin{array}{r}-0.001 \\
(0.003)\end{array}$ & $\begin{array}{r}-0.003 \\
(0.003)\end{array}$ \\
\hline Pseudo-R2 & 0.07 & 0.08 & 0.07 & 0.02 & 0.04 & 0.10 \\
\hline Observations & 141 & 135 & 132 & 141 & 135 & 135 \\
\hline
\end{tabular}


Table 4. The inequality of influence in the US banking sector.

\begin{tabular}{rc|cccc|c}
\hline \hline & Revolvers & Total moves & $\begin{array}{c}\text { Publ. to priv. } \\
\text { moves }\end{array}$ & $\begin{array}{c}\text { Priv. to publ. } \\
\text { moves }\end{array}$ & $\begin{array}{c}\text { Cumul. years } \\
\text { 2-sided moves }\end{array}$ & $\begin{array}{c}\text { Cum public office } \\
\text { in }\end{array}$ \\
\cline { 2 - 7 } $\boldsymbol{\Sigma}$ & 304 & 384 & 219 & 142 & 22 & 2256 \\
Ratio Index (RI) & 0.79 & 0.79 & 0.79 & 0.78 & 0.86 & 0.82 \\
SRDI & 0.231 & 0.237 & 0.223 & 0.261 & 0.320 & 0.259 \\
Goldman Sachs'\% & 0.27 & 0.27 & 0.23 & 0.32 & 0.32 & 0.31 \\
\hline \hline
\end{tabular}

Table 5. The inequality of influence in the US banking sector, by key regulatory agency.

\begin{tabular}{rlcccccccccc}
\hline \hline $\begin{array}{l}\text { Banks, ranked by bed } \\
\text { revenue }\end{array}$ & $\begin{array}{l}\text { Fed } \\
\text { system }\end{array}$ & Treasury & $\begin{array}{c}\text { White } \\
\text { House }\end{array}$ & $\begin{array}{l}\text { Congress } \\
\text { Bank\&Fin }\end{array}$ & $\begin{array}{l}\text { Trade } \\
\text { Rep. }\end{array}$ & SEC & $\begin{array}{l}\text { FBI, CIA } \\
\text { NSA }\end{array}$ & FDIC & CFTC & Total & $\begin{array}{l}\text { Other } \\
\text { agencies }\end{array}$ \\
\hline $\mathbf{\Sigma}$ & 53 & 40 & 26 & 24 & 10 & 13 & 10 & 8 & 3 & 187 & 117 \\
RI & 0.74 & 0.88 & 0.92 & 0.75 & 0.80 & 0.92 & 0.90 & 0.88 & 1.00 & 0.83 & 0.72 \\
SRDI & 0.238 & 0.356 & 0.384 & 0.290 & 0.394 & 0.433 & 0.343 & 0.314 & 0.672 & 0.281 & 0.178 \\
Goldman Sachs \% & 0.23 & 0.43 & 0.31 & 0.31 & 0.30 & 0.38 & 0.42 & 0.25 & 0.67 & 0.33 & 0.27 \\
\hline \hline
\end{tabular}




\section{References}

Adhikari, A., Derashid, C., and H. Zhang. 2006. "Public policy, political connections, and effective tax rates: Longitudinal evidence from Malaysia" Journal of Accounting and Public Policy, 25:574-595.

Amore, M.D., and M. Bennedsen. 2013. "The value of political connections in a low-corruption environment" Journal of Financial Economics, 110:387-402.

Ansolabehere, S., Figueiredo, J.M., and J.M. Snyder. 2003. "Why is There so Little Money in U.S. Politics?". Journal of Economic Perspective, 17(1):105-130.

Bertrand, M., Kramarz, F., Schoar, A., and D. Thesmar. 2006. "Politicians, firms and the political business cycle: evidence from France", Working Paper, University of Chicago.

Blanchard, O.J., and N. Kiyotaki. 1987. "Monopolistic competition and the effects of aggregate demand." The American Economic Review 77(4): 647-666.

Bond, P. and V. Glode. 2014. "The Labor Market for Bankers and Regulators", Review of Financial Studies, 27(9): 2539-2579.

Boubakri, N., Guedhami, O., Mishra, D., and W. Saffar. 2012. "Political connections and the cost of equity capital" Journal of Corporate Finance, 18:541-599.

Brezis, E.S. 2017. "Legal Conflicts of Interest of the Revolving Door", Journal of Macroeconomics. 52:175-188.

Brezis, E.S., and A. Weiss. 1997. "Conscientious regulation and post-regulatory employment restrictions" European Journal of Political Economy, 13:517-536.

Cingano, F., and P. Pinotti. 2013. "Politicians at work: the private returns and social costs of political connections" Journal of the European Economic Association, 11(2):433-465.

Cracau, D. and J.. Durán Lima. 2016. "On the Normalized Herfindahl-Hirschman Index: A Technical Note" International Journal Food System Dynamics 7 (4): 382-386.

De Haan, J. and D. Veltrop. 2014. "Regulatory Capture of Financial Sector Supervisors through their social identification with the Financial Sector", DNB working paper. 
Faccio, M. 2006. "Politically connected firms" The American Economic Review, 96:369-386.

Faccio, M. 2010. "Differences between Politically Connected and Non-connected Firms: A Cross-Country Analysis” Financial Management, 39(3):905-927.

Faccio, M., Masulis, M.W., and J.J. McConnell. 2006. "Political Connections and Corporate Bailouts” Journal of Finance, 61(6):2597-2635.

Fisman, R. 2001. "Estimating the Value of Political Connections" The American Economic Review, 91(4):1095-1102.

Goldman, E., Rocholl, J., and J. So. 2013. "Politically Connected Boards of Directors and the Allocation of Procurement Contracts" Review of Finance, 17(5):1617-1648.

Hellman, J., and D. Kaufmann. 2004. "The Inequality of Influence”, in J. Kornai and S. RoseAckerman (eds.), Building a Trustworthy State in Post-Socialist Transition, Palgrave Macmillan, New York.

Hellman, J., Jones, G., and D. Kaufmann. 2003. "Seize the state, seize the day: state capture and influence in transition economies" Journal of Comparative Economics, 31:751-773.

Johnson, S., and T. Mitton. 2003. "Cronyism and capital controls: evidence from Malaysia" Journal of Financial Economics, 67: 351-382.

Kaufmann, D., and P.C. Vicente. 2011. "Legal corruption" Economics \& Politics, 23(2): 195219.

Khwaja, A.I., and A. Mian. 2005. "Do Lenders Favor Politically Connected Firms? Rent Provision in an emerging Financial Market" The Quarterly Journal of Economics, 120(4):13711411.

Kramarz, F., and D. Thesmar. 2013. "Social network in the boardroom" Journal of the European Economic Association, 11(4):780-807.

Lucca, D., Seru, A., and F. Trebbi. 2014. The revolving door and worker flows in banking regulation. Journal of Monetary Economics, 65:17-32.

Laffont, J. J. and J. Tirole. 1996. A Theory of Incentives in Procurement and Regulation, Cambridge, MA: The MIT Press. 
Luechinger and Moser. 2014. "The Value of the Revolving Door: Political Appointees and the Stock Market”, Journal of Public Economics, 119:93-107.

Murphy, K.M., Shleifer, A., and R.W. Vishny. 1991. "The Allocation of Talent: Implication for Growth" The Quarterly Journal of Economics, 106(2):503-530.

OCDE. 2009. "Revolving Doors, Accountability and Transparency - Emerging Regulatory Concerns and Policy Solutions in the Financial Crisis”, Public Governance Committee, Paris.

Rajan, R., and L. Zingales. 1998. "Which capitalism? Lesson from the East Asian Crisis" Journal of Applied Corporate Finance, 11:40-48.

Romer, P.M. 1990. "Endogenous Technological Change.” Journal of Political Economy, 98: $71-103$.

Shive, S., and M. Forster. 2016. "The revolving door for financial regulators". Review of Finance, forthcoming.

Slinko, I., Yakovlev, E., and E. Zhuravskaya. 2005. "Law for Sale: Evidence from Russia" American Law and Economics Review, 7(1):284-318.

Transparency International. 2011. "Cabs for hire? Fixing the revolving door between government and business", Transparency International UK.

United Nations Conference on Trade and Development (2013), Handbook of Statistics, United Nations: New York and Geneva. 


\section{Appendix A - Proof of equations (23)-(24).}

From equations (7) and (8), and recalling that $r_{c}=\beta r$, we get that:

$$
\left(\frac{x_{c}}{x_{u}}\right)^{\alpha-1}=\frac{p_{c}}{p_{u}}=\beta
$$

In consequence:

$$
x_{c}=\beta^{1 / \alpha-1} x_{u}
$$

Moreover total capital, $\mathrm{K}$ is allocated between the big and small firms:

Therefore

$$
K=n_{u} x_{u}+n_{c} x_{c}
$$

which can be rewritten in the following form:

$$
K=n x_{u} \text { where } n=n_{u}+n_{c} \beta^{1 / \alpha-1} .
$$

In consequence: $\quad x_{c}=\beta^{1 / \alpha-1} K / n$

Substituting (A5) into the demand for constrained and unconstrained firms (16) and (22), we get:

$$
\begin{aligned}
& H_{c}=\bar{H}_{c}=\frac{\phi r \beta^{\alpha / \alpha-1} K}{(1+\lambda) n q}=D_{c} \\
& H_{u}=\bar{H}_{u}=\frac{\phi r K}{n q}=D_{u}
\end{aligned}
$$




\section{Appendix B - methodological notes}

\section{Data sources}

The main sources of raw data on the revolving door are on the one hand, the Opensecrets.org website, managed by the Center for Responsive Politics, and on the other hand Littlesis.org. Opensecrets.org and Littlesis.org provides open-access and documented information on the revolving door process and lobbying in the US political system. ${ }^{20}$

Raw information on revolver's identity, movements between public and private offices, career path (position occupied in the public and private sectors, entry/exit dates in public and private offices) is drawn from these two websites, and then cross-checked, further documented, corrected when necessary, by complementary information sources: Linkedin, Wikipedia, Muckety.org, Beyond.com, Zoominfo.com, Bloomberg.com, Businessweek, Business Insider, journal articles and other web sources. When this additional source cannot be confirmed entryexit dates in the public and private sectors, dates provided by open secret are taken. If multiple converging additional sources (e.g. Linkedin and Businessweek) diverge with opensecrets entry-exit dates, the former are taken into account.

Once data is retrieved and cross-checked, a second of data collection round is undertaken by searching on google potential additional revolved regulators using the following association of keywords: "name of the company + revolving door", "name of the company + political appointment", "name of the company + lobbyist".

\section{Revolvers}

Individuals considered as revolvers are current (former) employees in private firms who are former (current) members of a US federal agency: ministry, parliament, or a relevant regulatory agency. ${ }^{21}$ Former employees of WaMu, Chase Manhattan Bank, Dime Bancorp and Bank One are considered as part of JP Morgan stock of revolvers. Former employees of Primerica and

\footnotetext{
${ }^{20}$ See for instance Ansolabehere, et al., (2003).

${ }^{21}$ Local or State regulatory agencies - such as the NY housing regulatory agency - as well as foreign agencies such as the European Central Bank - are therefore excluded from the analysis. However, the examination of the data showed that many firms hire revolvers that at some point of their career joined the Advisory Board of a local Federal Reserve Bank, especially the Federal Reserve Bank of New York, position that can be hold simultaneously with a job in the private sector. Given the many scandals that arose from the leakage Federal Reserve System's secret documents from the NY Fed towards financial firms, we considered individuals holding position in both private firms and local Federal Reserve Banks as revolvers.
} 
Travelers group are considered as part of Citigroup stock of revolvers. Former employees of Merrill Lynch and Security Pacific Bank are considered as part of Bank of America stock of revolvers. Former employees of West One Bank are considered as US Bancorp's stock of revolvers.

People are also sorted by the influence and power of their government positions. For those individuals with complex careers and had been in a government position multiple times, the positions that were taken in account are the most influential positions during revolvers' careers.

Influential positions considered are the following:

- Chairman of the Federal Reserve, and New York's Fed

- Chief of Staff to the White House

- White House: Assistant to the President, congressional liaison

- Chief of Staff/ Assistant Secretary of Treasury

- Congressmen

- Deputy/Director of the National Economic Council

- Chairman and directors of the Securities and Exchange Commission (SEC)

- Managing Executive of SEC's Division of Enforcement

- Chief of Staff/Chairman of Commodities Futures Trading Commission

- Deputy Secretary/Secretary/Assistant Secretary/Under Secretary of US State Department

- Secretary of Navy

- Secretary of Treasury

- Ambassador

- Head/Deputy of the Office of the United States Trade Representative

- Chief of Staff to President's Council of Economic Advisors

- Director of Office of Management and Budget

- Director of Congressional Budget Office

- National Security Advisor

- Attorney General (Deputy)

- Consul to the President

- State Governors

- Chief of Staff to Chairman of the US Consumer Product Safety Commission

- Director, chief of staff of the Federal Housing Finance Agency 
- Director, chief of staff of the Federal Deposit Insurance Corporation

- Member of the Congress' Bank and Finance Committees

All other positions in federal agencies, boards or commissions are less influential. Positions in local agencies, commissions or boards are not considered, except for members of advisory boards of local agencies of the Federal Reserve System and chief of staff of State governors, who are recorded as less influential revolvers. We also identify individuals moving from (into) powerful agencies charged with financial matters: the Treasury (including the Office of the Comptroller of the Currency), the White House, The Federal Deposit Insurance Company, the Commodity Future Trading Commission, Intelligence Agencies ${ }^{22}$ (FBI, CIA, NSA), the Security and Exchange Commission, the Federal Reserve System, the Congress's Bank and Finance committees, and the US Trade Representative ${ }^{23}$. (In Table 1, we have presented only 5 agencies).

The specific case of the Obama-Biden 2008 transition period: This period allowed many banks' employees integrating Obama transition team without imposing them to leave their position in the private financial sector. We consider the membership to this team as less influential position in public office.

\section{Typology of revolving door movements}

We focus on both private-to-public and public-to-private revolving door movements. While the model emphasizes how revolvers sell their BC after leaving public office, it is also common to see private sector officers cashing in huge exit bonanza before taking public responsibilities $^{24}$. Therefore, three types of revolving door flows are identified:

- Type 1, public-to-private: former members of a relevant ministry, administration, or legislature currently hold an executive position in a regulated company.

\footnotetext{
${ }^{22}$ Intelligence agencies play a key role in enforcing financial regulation and prosecuting cases of financial malpractices before the courts. The strong interest of financial firms in recruiting members of intelligence agencies can be illustrated by the recent hiring of Patrick Carroll, former FBI agent who headed securities fraud and white collar crime and who locked up Bernard Madoff, by Goldman Sachs.

See for instance http://fortune.com/2015/05/26/goldman-sachs-hire-fbi-agent/

${ }^{23}$ We also considered the US Trade Representative as a finance-related agency because of its key role for banks' implementation in foreign markets, notably through trade agreement negotiations.

${ }^{24}$ See for instance Samantha Lachamn, "Hillary Clinton Backs Bill That Would Ban 'Golden Parachutes' For Wall Street Bankers", The Huff, Aug 31, 2015.
} 
- Type 2, private-to-public: former executives of a regulated company are currently members of a relevant ministry, administration, or legislature.

- Type 3a, symmetric two-sided: when individuals undertake symmetric movements from a private firm to a public agency to the same private firm, or from a public agency to a private firm to the same public agency, they can favour firms both during and after their term in public office. Therefore, an individual undertaking this revolving door path is associated with three revolving door movements for the company.

- Type 3b, asymmetric two-sided: we should note that there exist also asymmetric twosided movements from a given public agency to a private agency and then to another public agency. From our point of view, they are counted as two separate one-sided movements (types 1 and 2).

The data and statistics are presented in Tables C1 and C.2. It should be noted that $37 \%$ of these movements are made of private-to-pubic moves, $57 \%$ of public-to-private moves, and $6 \%$ of symmetric moves.

\section{The banks}

The 20 top commercial banks are selected according to the Fortune 500 ranking of commercial banks (with regard to their total revenue). Other famous financial firms strongly involved in the revolving door - such as Fannie Mae, or Blackstone - are not commercial banks and are therefore not included in the sample. This sample is meant to be representative, but not fully exhaustive, of the revolving door practices in the US financial sector. 


\section{Appendix C. Distribution of bureaucratic capital among firms and regulatory agencies}

Table C.1. The revolving door in the top 20 US commercial Banks

\begin{tabular}{|c|c|c|c|c|c|c|c|c|c|}
\hline Bank & $\begin{array}{c}\text { Revenues in } 2015 \\
\text { (in \$M) }\end{array}$ & $\begin{array}{l}\text { Employees } \\
\text { in } 2015 \\
\end{array}$ & $\begin{array}{l}\text { Profits in } 2015 \\
\quad \text { (in \$M) }\end{array}$ & Revolvers & Moves & $\begin{array}{c}\text { Public-to-bank } \\
\text { moves }\end{array}$ & $\begin{array}{c}\text { Bank-to-public } \\
\text { moves }\end{array}$ & Two-sided moves & $\begin{array}{l}\text { Cumulated years } \\
\text { in public offices }\end{array}$ \\
\hline JP Morgan & 102102 & 241359 & 21762 & 62 & 82 & 50 & 27 & 5 & 436 \\
\hline Bank of America & 95181 & 223715 & 4833 & 29 & 36 & 22 & 12 & 2 & 227 \\
\hline Citigroup & 90646 & 241000 & 7313 & 55 & 71 & 41 & 25 & 5 & 401 \\
\hline Wells Fargo & 88372 & 264500 & 23057 & 12 & 12 & 10 & 2 & 0 & 87 \\
\hline Goldman Sachs & 40085 & 34000 & 8477 & 81 & 102 & 50 & 45 & 7 & 698 \\
\hline Morgan Stanley & 37953 & 55802 & 3467 & 15 & 18 & 9 & 8 & 1 & 75 \\
\hline American Express & 35999 & 54000 & 5885 & 14 & 15 & 9 & 5 & 0 & 75 \\
\hline Capitale 1 Financial & 23877 & 46000 & 4428 & 8 & 13 & 7 & 4 & 2 & 48 \\
\hline US Bancorp & 21392 & 66750 & 5851 & 1 & 1 & 0 & 1 & 0 & 3 \\
\hline Bank of NY Mellon & 16386 & 50300 & 2567 & 6 & 7 & 4 & 3 & 0 & 35 \\
\hline PNC Financial Services & 16281 & 51666 & 4184 & 7 & 8 & 5 & 3 & 0 & 53 \\
\hline State Street Corp & 10687 & 29970 & 2037 & 2 & 2 & 1 & 1 & 0 & 3 \\
\hline BB\&T Corp & 9926 & 33400 & 2151 & 1 & 2 & 1 & 1 & 0 & 7 \\
\hline Ally Financial & 9790 & 6900 & 1150 & 0 & 0 & 0 & 0 & 0 & 0 \\
\hline Discover Fin. Services & 9611 & 14676 & 2323 & 2 & 2 & 1 & 1 & 0 & 29 \\
\hline Suntrust Bank & 8707 & 24638 & 1774 & 4 & 6 & 4 & 2 & 0 & 26 \\
\hline Fifth Third Bancorp & 6503 & 18351 & 1481 & 1 & 1 & 1 & 0 & 0 & 26 \\
\hline Regions Financial & 5428 & 23723 & 1155 & 2 & 2 & 2 & 0 & 0 & 18 \\
\hline M\&T Bank & 4736 & 15196 & 1066 & 2 & 4 & 2 & 2 & 0 & 9 \\
\hline Northern trust & 4513 & 15400 & 812 & 0 & 0 & 0 & 0 & 0 & 0 \\
\hline
\end{tabular}


Table C.2. Sector distribution of revolvers and the inequality of influence over key regulatory agencies.

\begin{tabular}{|c|c|c|c|c|c|c|c|c|c|c|c|}
\hline $\begin{array}{l}\text { Banks, ranked by } \\
\text { revenue }\end{array}$ & $\begin{array}{l}\text { Fed } \\
\text { system }\end{array}$ & Treasury & $\begin{array}{l}\text { White } \\
\text { House }\end{array}$ & $\begin{array}{l}\text { Congress } \\
\text { Bank\&Fin }\end{array}$ & $\begin{array}{l}\text { Trade } \\
\text { Rep. }\end{array}$ & SEC & $\begin{array}{l}\text { FBI, CIA } \\
\text { NSA }\end{array}$ & FDIC & CFTC & Total & $\begin{array}{l}\text { Other } \\
\text { agencies }\end{array}$ \\
\hline JP Morgan & 14 & 4 & 6 & 7 & 4 & 1 & 1 & 2 & 0 & 39 & 23 \\
\hline BofA & 4 & 3 & 1 & 0 & 0 & 5 & 2 & 1 & 0 & 16 & 13 \\
\hline Citigroup & 9 & 8 & 9 & 5 & 1 & 1 & 3 & 2 & 1 & 39 & 16 \\
\hline Wells Fargo & 0 & 3 & 0 & 0 & 0 & 0 & 0 & 0 & 0 & 3 & 9 \\
\hline Goldman Sachs & 12 & 17 & 8 & 6 & 3 & 5 & 3 & 2 & 2 & 58 & 23 \\
\hline Morgan Stanley & 1 & 3 & 1 & 1 & 1 & 0 & 0 & 1 & 0 & 8 & 7 \\
\hline American Express & 1 & 0 & 1 & 0 & 1 & 1 & 0 & 0 & 0 & 4 & 10 \\
\hline Capitale 1 Fin. & 0 & 0 & 0 & 0 & 0 & 0 & 0 & 0 & 0 & $\mathbf{0}$ & 8 \\
\hline US Bancorp & 0 & 0 & 0 & 0 & 0 & 0 & 0 & 0 & 0 & $\mathbf{0}$ & 1 \\
\hline Bank of NY Mel. & 1 & 2 & 0 & 0 & 0 & 0 & 1 & 0 & 0 & 4 & 2 \\
\hline PNC Fin. Services & 4 & 0 & 0 & 1 & 0 & 0 & 0 & 0 & 0 & 5 & 2 \\
\hline State Street Corp & 1 & 0 & 0 & 0 & 0 & 0 & 0 & 0 & 0 & 1 & 1 \\
\hline BB\&T Corp & 1 & 0 & 0 & 0 & 0 & 0 & 0 & 0 & 0 & $\mathbf{1}$ & 0 \\
\hline Ally Financial & 0 & 0 & 0 & 0 & 0 & 0 & 0 & 0 & 0 & $\mathbf{0}$ & 0 \\
\hline Discover Fin. Serv. & 1 & 0 & 0 & 1 & 0 & 0 & 0 & 0 & 0 & 2 & 0 \\
\hline Suntrust Bank & 3 & 0 & 0 & 1 & 0 & 0 & 0 & 0 & 0 & 4 & 0 \\
\hline $5^{\text {th }} 3^{\text {rd }}$ Bancorp & 0 & 0 & 0 & 1 & 0 & 0 & 0 & 0 & 0 & 1 & 0 \\
\hline Regions Financial & 0 & 0 & 0 & 1 & 0 & 0 & 0 & 0 & 0 & 1 & 1 \\
\hline M\&T Bank & 1 & 0 & 0 & 0 & 0 & 0 & 0 & 0 & 0 & $\mathbf{1}$ & 1 \\
\hline Northern trust & 0 & 0 & 0 & 0 & 0 & 0 & 0 & 0 & 0 & $\mathbf{0}$ & 0 \\
\hline Sum & 53 & 40 & 26 & 24 & 10 & 13 & 10 & 8 & 3 & 187 & 117 \\
\hline RI & 0.74 & 0.88 & 0.92 & 0.75 & 0.80 & 0.92 & 0.90 & 0.88 & 1.00 & 0.83 & 0.72 \\
\hline SRDI & 0.238 & 0.356 & 0.384 & 0.290 & 0.394 & 0.433 & 0.343 & 0.314 & 0.672 & 0.281 & 0.178 \\
\hline Goldman Sachs \% & 0.23 & 0.43 & 0.31 & 0.31 & 0.30 & 0.38 & 0.42 & 0.25 & 0.67 & 0.33 & 0.27 \\
\hline
\end{tabular}

